\title{
Isolation of Lignocellulose-derived Sugars, Co-fermentation of Lactic Acid Bacteria Strains, and Evaluation of L-lactic Acid Productivity
}

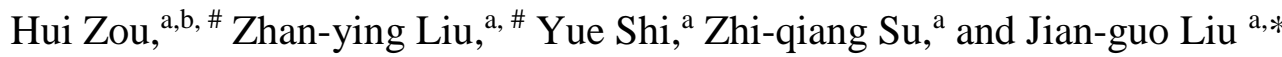 \\ High-productivity lactic acid bacteria (LAB) strains were screened and their \\ capability to ferment lignocellulose-derived sugars into lactic acid were \\ evaluated. Fifteen LAB strains were successfully isolated from cow dung, \\ haystack, and sheep manure, respectively. Four relatively good strains \\ were selected based on Gram stain, colony morphology, and catalase \\ activity tests. The four strains and commercial inoculants (Lactobacillus \\ pentosus and Enterococcus faecalis) were used to ferment cellobiose/ \\ glucose/xylose to produce high-purity L-lactic acid. One of the strains (N4) \\ presented the highest production of L-lactic acid after fermentation for 12 \\ $\mathrm{h}$ and showed a L-lactic acid production of $15.1 \mathrm{~g} / \mathrm{L}, 18.5 \mathrm{~g} / \mathrm{L}$, and $2.8 \mathrm{~g} / \mathrm{L}$ \\ and a productivity of $1.01 \mathrm{~g} \cdot \mathrm{L}^{-1} \cdot \mathrm{h}^{-1}, 3.68 \mathrm{~g} \cdot \mathrm{L}^{-1} \cdot \mathrm{h}^{-1}$, and $0.47 \mathrm{~g} \cdot \mathrm{L}^{-1} \cdot \mathrm{h}^{-1}$ by \\ metabolizing cellobiose, glucose, and xylose, respectively. Through a \\ phylogenetic tree analysis, strain N4 was identified as Enterococcus \\ faecium and named Enterococcus faecium N4. Enterococcus faecium N4 \\ has a great potential to ferment lignocellulose-derived sugars into L-lactic \\ acid.
}

Keywords: Lignocellulose-derived sugars; L-lactic acid; Lactic acid bacteria; Microbial isolation; Phylogenetic tree

Contact information: a: Department of Environmental Science and Engineering, Inner Mongolia University of Technology, Hohehot 010000, China; $b$ : School of Energy and Environmental Engineering, University of Science and Technology Beijing, Beijing 100083, China; \#: These authors contributed equally to this work

*Corresponding author: liujianguo863@163.com

\section{INTRODUCTION}

Lignocellulosic biomass is an organic material derived from a biological origin; it is the most abundant global source of biomass but large amounts of it have been unutilized (Lin and Tanaka 2006; Sun et al. 2006). It is mainly composed of cellulose, hemicellulose, and lignin, which account for $90 \%$ of the dry matter, as well as small amounts of minerals, oils, and other components (Molina-Sabio and Rodríguez-Reinoso 2004; Yang et al. 2009; Balat 2011). Biomass includes forest and crop residues (Chen and Lee 1997; Melzoch et al. 1997), municipal solid waste (John et al. 2007), waste paper (McCaskey et al. 1994), and wood (Linko et al. 1984). Its ratio of effective utilization is relatively low, so it has a great potential for biomass energy materials. In China, more than 700 million tons of crop straw are produced annually, more than $33 \%$ of which is burned or discarded. The burning or discarding of crop straw results in environmental pollution and energy waste.

Lactic acid (LA) is one of the most important chemical commodities. Recently, it has been employed in new applications in the plastics industry, whereby polylactic acid (PLA) is utilized as a biodegradable and biocompatible plastic material, and the PLA production process requires chirally pure L-lactic acid to be synthesized (Tanaka et al. 2002; Zheng et al. 2017). 
Chirally pure LA can be produced through microbial fermentation, which is an alternative to chemically derived plastics (Drumright et al. 2000; Xu et al. 2004). Such an approach can potentially reduce net emissions of carbon dioxide and the demand for petroleum (Neu et al. 2016). Furthermore, microbial production of lactic acid is economically important because of the prospect of using cheap and widely available feedstock materials, such as lignocelluloses (Akerberg and Zacchi 2000; Hofvendahl and Hahn-Hgerdal 2000). Research has shown that effective utilization of lignocellulosederived sugars can reduce the production cost of biomaterials by as much as $25 \%$ (Mohamed et al. 2011).

Conventional processes of producing lactic acid from lignocellulosic biomass involve pretreatment, enzymatic hydrolysis, fermentation, separation, and purification (Abdel-Rahman et al. 2011). Pretreatment includes physical (milling and grinding), chemical (alkali, dilute acid, oxidizing agents, and organic solvents), physicochemical (steam explosion/autohydrolysis, hydrothermolysis, and wet oxidation), and biological methods (Sun et al. 1995; Chandel et al. 2007).

Enzymatic hydrolysis is the most promising means to yield fermentable sugars from pretreated lignocellulosic biomass, and such a process makes it possible to produce LA when utilizing polysaccharides as a carbon source. Cellulases and hemicellulases are two general categories of enzymes necessary to convert cellulose and hemicellulose into soluble sugars ( $\mathrm{Yu}$ and Zhang 2004). The hydrolysate of a lignocellulosic biomass is a mixture of hexoses (e.g., glucose) and pentoses (e.g., xylose and arabinose). Lignin cannot be used for lactic acid fermentation.

The effective utilization of hemicellulose-derived sugars, rather than relying on the cellulose-derived sugars alone, can reduce the production cost of biomaterials by as much as $25 \%$ (Okano et al. 2010). Fermentation technologies must be cost-competitive with chemical synthesis to validate the use of biotechnological processes on an industrial scale (Martinez et al. 2013; Zhang et al. 2015). In comparison with separate hydrolysis and fermentation (SHF) technology, the simultaneous saccharification and fermentation (SSF) technology offers many advantages, such as reduced reactor volume, rapid processing time, and an enhanced rate of hydrolysis (Temer et al. 2014). But the activity of $\beta$-glucosidase in SSF process is very low, so it causes significant accumulation of cellobiose that cannot be hydrolyzed to glucose (Xia and Shen 2004).

Studies have shown that cellobiose strongly inhibits endoglucanase and cellobiose hydrolysis, and this inhibition is much stronger than for glucose (Tomme et al.1995; Levine et al. 2010). Thus, highly active $\beta$-glucosidase is important in the process of L-lactic acid fermentation using lignocellulosic biomass (Chandel et al. 2007). The use of partial cellobiose as the carbon source metabolized to L-lactic acid directly can shorten the production pathway of L-lactic acid in SSF and significantly improve the efficiency of Llactic acid (Temer et al. 2014).

This study identifies a strain of L-lactic acid bacteria that can metabolize lignocellulose-derived sugars with high efficiency to overcome the problem of cellobiose inhibition in the degradation process of lignocellulosic biomass and to improve fermentation efficiency. The L-lactic acid bacteria obtained can be used for lignocellulosic biomass utilization and high-optical-purity L-lactic acid production. The ideal strain was identified through a $16 \mathrm{~S}$ rRNA gene sequence similarity analysis. 


\section{EXPERIMENTAL}

\section{Materials}

Microorganism and culture media

Lactobacillus pentosus 22156 (LP) and Enterococcus faecalis 21057 (EF) were obtained from the China Center of Industrial Culture Collection (Beijing, China). Three samples (cow dung, haystack, and sheep manure) were collected from various sources in Hohhot City, China. The modified Man, Rogosa, and Sharpe (mMRS) medium was used for the cell growth, inoculum preparation, and fermentation as reported previously (Shibata et al. 2007), except that glucose, cellobiose, or xylose was used as the carbon source for the mMRS-glucose, mMRS-cellobiose, or mMRS-xylose medium with a sugar content of $2 \%(\mathrm{w} / \mathrm{v})$, respectively. Complete medium (CM)-cellobiose was used for cell cultivation (Tokuhiro et al. 2008).

\section{Methods}

Isolation methods with cellobiose as the carbon source

The samples $(5 \mathrm{~g})$ were blended with $100 \mathrm{~mL}$ of sterilized distilled water. Serial dilutions were performed to isolate lactic acid bacteria (LAB) strains by using mMRScellobiose agar with calcium carbonate as the medium. The cultures were grown on mMRS-cellobiose agar at $30^{\circ} \mathrm{C}$ for $12 \mathrm{~h}$ to $24 \mathrm{~h}$. The large transparent circle of LAB stains was removed and transferred to the CM-cellobiose agar medium. Three samples were selected from $15 \mathrm{LAB}$ strains, and each LAB colony was purified twice by streaking on mMRS agar and then preserved at $-4{ }^{\circ} \mathrm{C}$. The 15 strains (C1-C5, N1-N5, and $\left.\mathrm{Y} 1-\mathrm{Y} 5\right)$ were inoculated in mMRS-glucose and mMRS-xylose media for lactic acid fermentation. Fermentation was conducted at $30{ }^{\circ} \mathrm{C}$ with agitation at $200 \mathrm{rpm}$, and the initial $\mathrm{pH}$ was adjusted to 7.0 with calcium carbonate; the excess calcium carbonate was added to maintain a neutral $\mathrm{pH}$ during the process (Xu et al. 2007). Four strains (C3, N4, Y3, and Y5) were selected because of their high acidification activity. Gram stain, colony morphology, and catalase activity were determined according to the methods for LAB identification.

\section{Glucose/xylose as carbon sources for lactic acid fermentation}

To investigate the acid-producing capacity of the four strains in glucose/xylose substrates, each strain was cultivated overnight in $100 \mathrm{~mL}$ of mMRS-glucose and mMRSxylose media at $37^{\circ} \mathrm{C}, 200 \mathrm{rpm}$, and a pH of 7.0 . Then, $10 \mathrm{~mL}$ of the culture medium was inoculated in $90 \mathrm{~mL}$ of mMRS-glucose and $90 \mathrm{~mL}$ of mMRS-xylose media for $24 \mathrm{~h}$. Afterwards, $4 \mathrm{~mL}$ of the fermentation broth was sampled every $3 \mathrm{~h}$. After centrifugation, the L- and D-lactic acids in the samples were detected through high-performance liquid chromatography (Alltech, Nicholasville, KY, USA) at $25^{\circ} \mathrm{C}$. The mobile phase was $60 \%$ methanol (v/v) at a flow rate of $0.2 \mathrm{~mL} / \mathrm{min}$. The instrument was equipped with a tunable UV detector at $210 \mathrm{~nm}$. Two commercial LAB inoculants, LP and EF, were used to compare their effectiveness with that of the isolates.

Species identification by $16 S$ rRNA sequencing

To specifically identify the best bacterial strain, $16 \mathrm{~S}$ rRNA sequencing was employed. The genomic DNA of bacterial strains was extracted through the method mentioned in (Sambrook and Russell 2008) and stored at $-20^{\circ} \mathrm{C}$ prior to use. Then, $1 \mu \mathrm{L}$ of diluted DNA was used as a template for the PCR reactions. The PCR primers were 27F 
(5'-AGA GTT TGA TCC TGG CTC AG-3') and 1492R (5'-TAC GGC TAC CTT GTT ACG ACT-3') (Cai et al. 1999). The PCR products were purified, cloned, and sequenced by the Beijing Center for Physical and Chemical Analysis. The 16S rDNA sequences were aligned with $16 \mathrm{~S}$ rRNA sequences from GenBank to identify the organisms through a MEGA analysis. Finally, the 16S rRNA gene sequence of the isolate was compared with the sequences from the LAB-type strains contained in GenBank (Kimura and Ohta 1972).

\section{RESULTS AND DISCUSSION}

\section{LAB Isolation with Cellobiose as the Carbon Source}

The lignocellulose-derived sugars are mainly cellobiose, hexose (glucose), and pentose (xylose and arabinose) (Mohamed et al. 2011). Thus, the use of mixed sugar fermentation to improve the yield of lactic acid is critical (Gao et al. 2011; Ouyang et al. 2013; Pessione et al. 2014).

In the first stage, 15 bacterial isolates were obtained from three environmental samples according to the procedures described above. Four relatively good strains $(\mathrm{C} 3$, $\mathrm{N} 4, \mathrm{Y} 3$, and Y5) were selected according to the results of Gram stain, colony morphology, and catalase activity tests. The four strains and two commercial inoculants used cellobiose (sugar content of $2 \%(\mathrm{w} / \mathrm{v})$ ) as the substrate for lactic acid fermentation. The control group was without adding cellobiose. Results are shown in Fig. 1. The LA concentration was generally less than $1 \mathrm{~g} / \mathrm{L}$ in the control group due to the absence of a carbon source. Therefore, the effect of the medium without a carbon source on the lactic acid production was ignored. This was because the amount of nitrogen in beef extract, peptone, and yeast powder was much larger than the amount of carbon. This imbalanced carbon-nitrogen ratio seriously affected the growth of LAB and the lactic acid yield. Strains C3, Y3, Y5, and N4 showed high lactic acid production, and they were used as the primary screening bacteria.

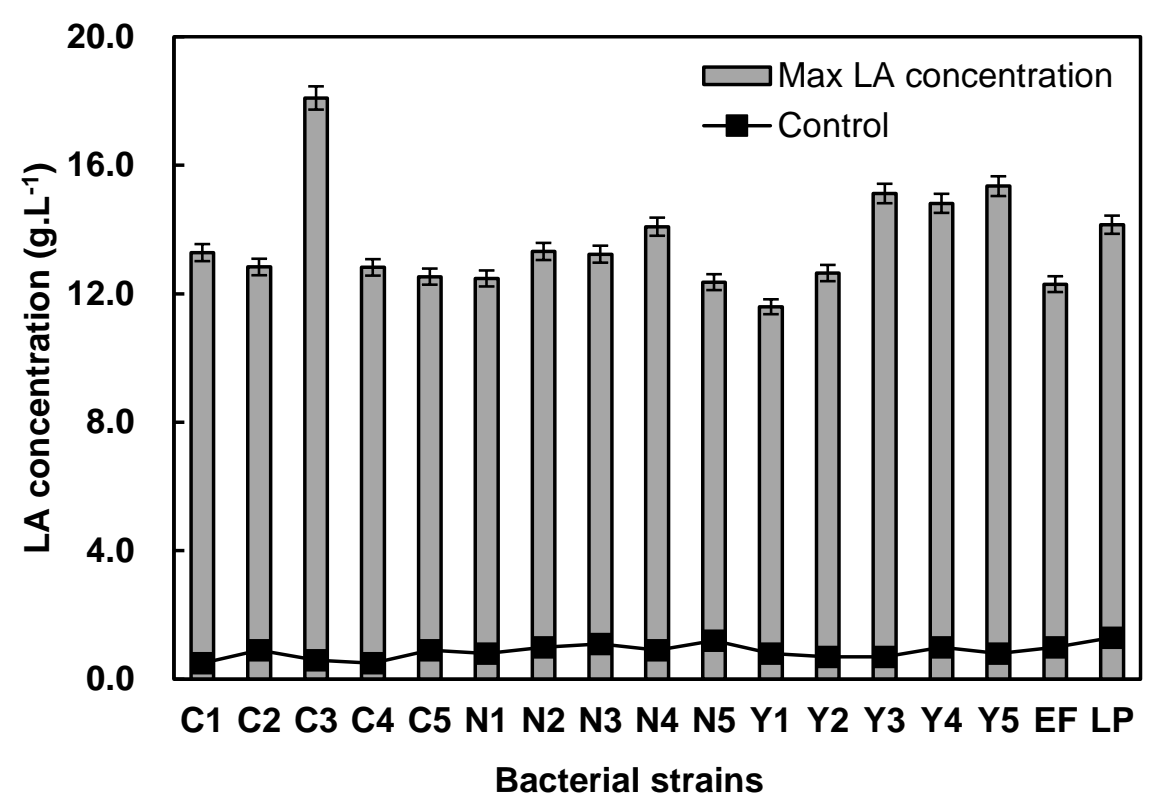

Fig. 1. Lactic acid production of bacteria from haystack (C1 through $\mathrm{C5}$ ), cow dung (N1 through $\mathrm{N} 5)$, sheep manure (Y1 through Y5), lactobacillus pentose (LP), Enterococcus faecalis (EF), and the control group experiments at $37^{\circ} \mathrm{C}, 200 \mathrm{rpm}$, initial pH 7.0 for $12 \mathrm{~h}$ of fermentation (working

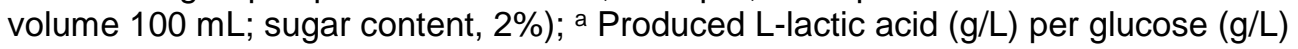


The goal of this work was to screen for high-optical-purity LAB. According to the conventional definition, LAB with an optical purity more than $80 \%$ is considered homofermentative LAB (Arriola et al. 2011). Figure 2 shows that the optical purity of Y3, Y5, N4, and Lactobacillus pentosus exceeded 95\%; it follows that these strains could be potentially applied to produce L-lactic acid. Strain Y5 had the highest lactic acid production rate. After $21 \mathrm{~h}$ of fermentation, Y5 accumulated an L-lactic acid yield of 0.82 $\mathrm{g} / \mathrm{g}$ cellobiose consumed. This phenomenon indicated that the strains selected from animal feces had better metabolic cellobiose capacity than natural plant strains. This might be the due to the presence of some LAB strains in the intestines of herbivores. The intestinal acidic environment was equivalent to a natural culture medium, so high-optical-purity LAB was obtained by suitable long-term natural selection in the intestinal tract. Strain N4 had an L-lactic acid yield of $0.78 \mathrm{~g} / \mathrm{g}$ after $12 \mathrm{~h}$ of fermentation.

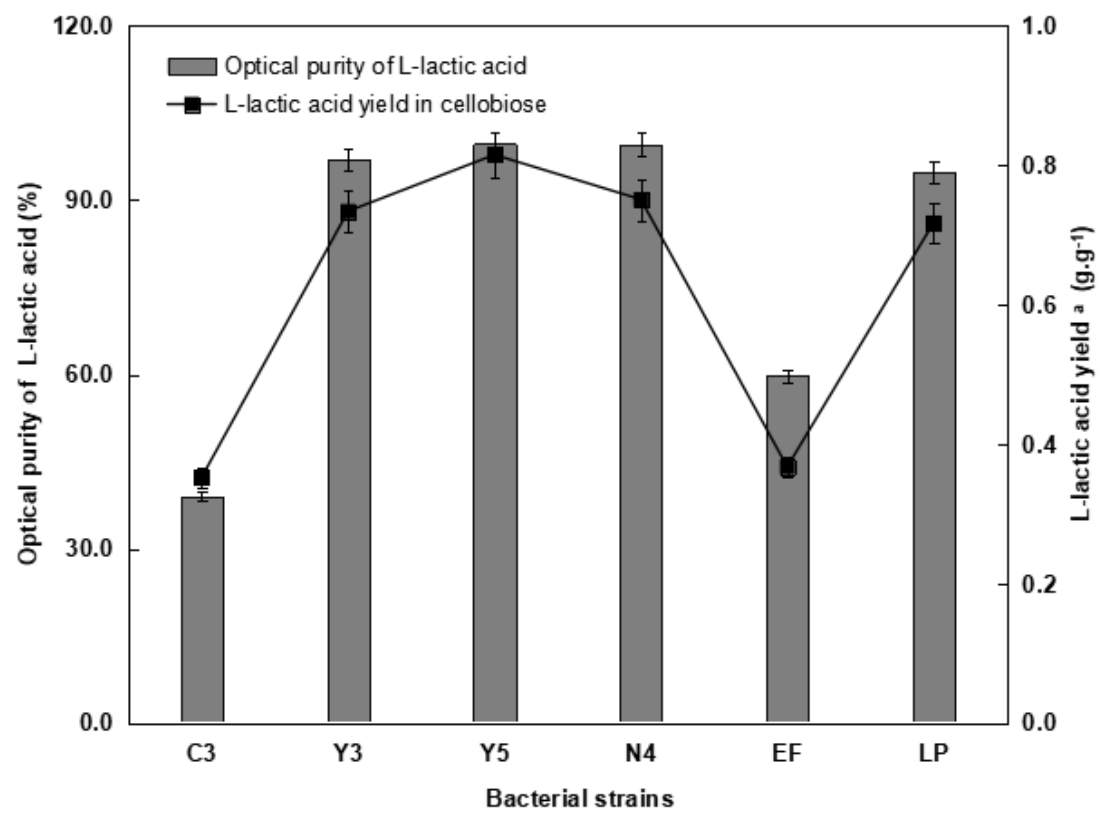

Fig. 2. L-lactic acid yield and optical purity of L-lactic acid from cellobiose at $37^{\circ} \mathrm{C}, 200 \mathrm{rpm}$, initial pH 7.0 for $12 \mathrm{~h}$ fermentation (working volume $100 \mathrm{~mL}$; sugar content, $2 \%$ ); a: Produced Llactic acid $(\mathrm{g} / \mathrm{L})$ per glucose $(\mathrm{g} / \mathrm{L})$

\section{Analysis of L-lactic Acid Production with Glucose as the Carbon Source}

According to the above conclusions, the strains (Y3, Y5, N4, and LP) metabolized cellobiose into high-optical-purity L-lactic acid; therefore, further investigation to metabolize glucose was necessary.

In this part, glucose as the carbon source for lactic acid fermentation was investigated; the concentration was $2 \%(\mathrm{w} / \mathrm{v})$. Figure 3 shows the results. The four strains had a stronger capability to metabolize glucose to lactic acid than cellobiose, and strain N4 had the highest L-lactic acid concentration and productivity. After fermentation for $6 \mathrm{~h}$, lactic acid in strain N4 was achieved with a production of $18.5 \mathrm{~g} / \mathrm{L}$ and a L-lactic acid yield of $0.93 \mathrm{~g} / \mathrm{g}$ glucose consumed. The reason might be that in the metabolism of homofermentative LAB, glucose was metabolized to lactic acid via the Embden-MeyerhofParnas pathway (EMP) (Sun and Cheng 2002; John et al. 2006). However, cellobiose was hydrolyzed into glucose to enter the EMP pathway. Therefore, the LAB strains easily metabolized the monosaccharides. 


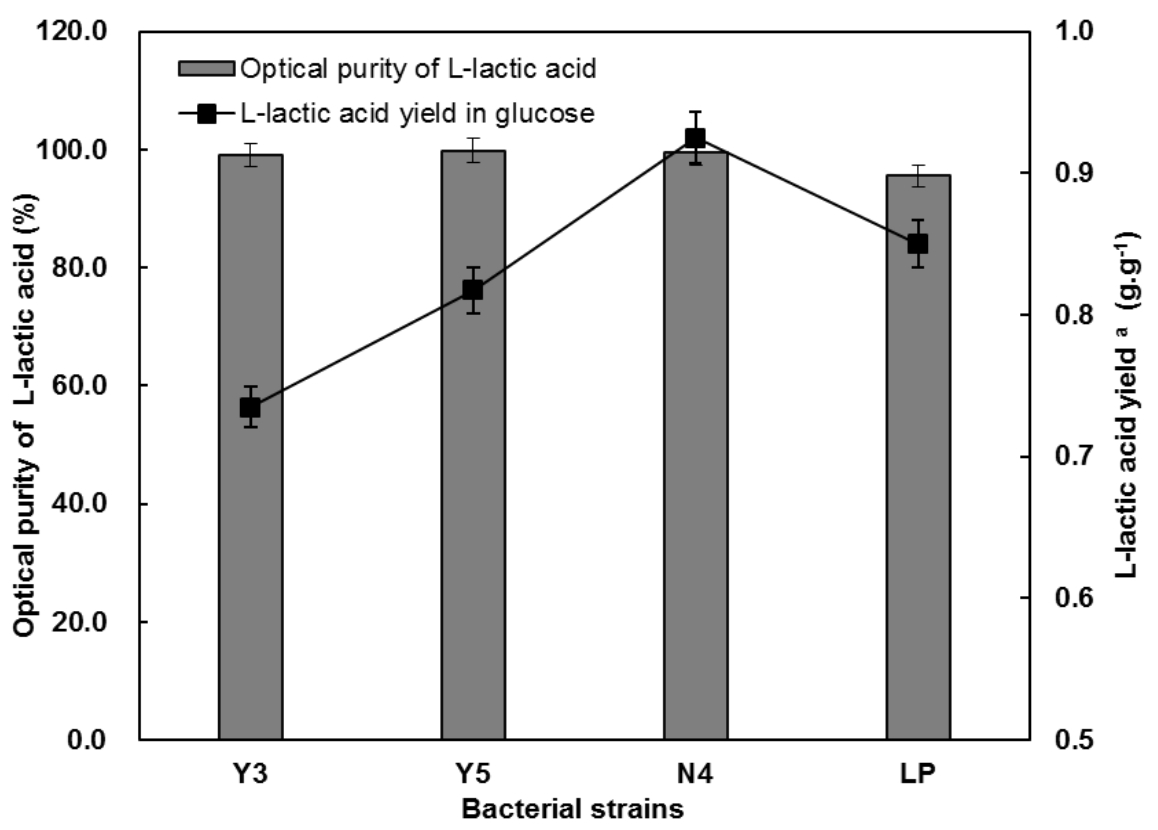

Fig. 3. L-lactic acid yield and optical purity of lactic acid from glucose at $37^{\circ} \mathrm{C}, 200 \mathrm{rpm}$, initial pH 7.0 for $12 \mathrm{~h}$ fermentation (working volume $100 \mathrm{~mL}$; sugar content, $2 \%$ ); a: Produced L-lactic acid $(\mathrm{g} / \mathrm{L})$ per glucose $(\mathrm{g} / \mathrm{L})$

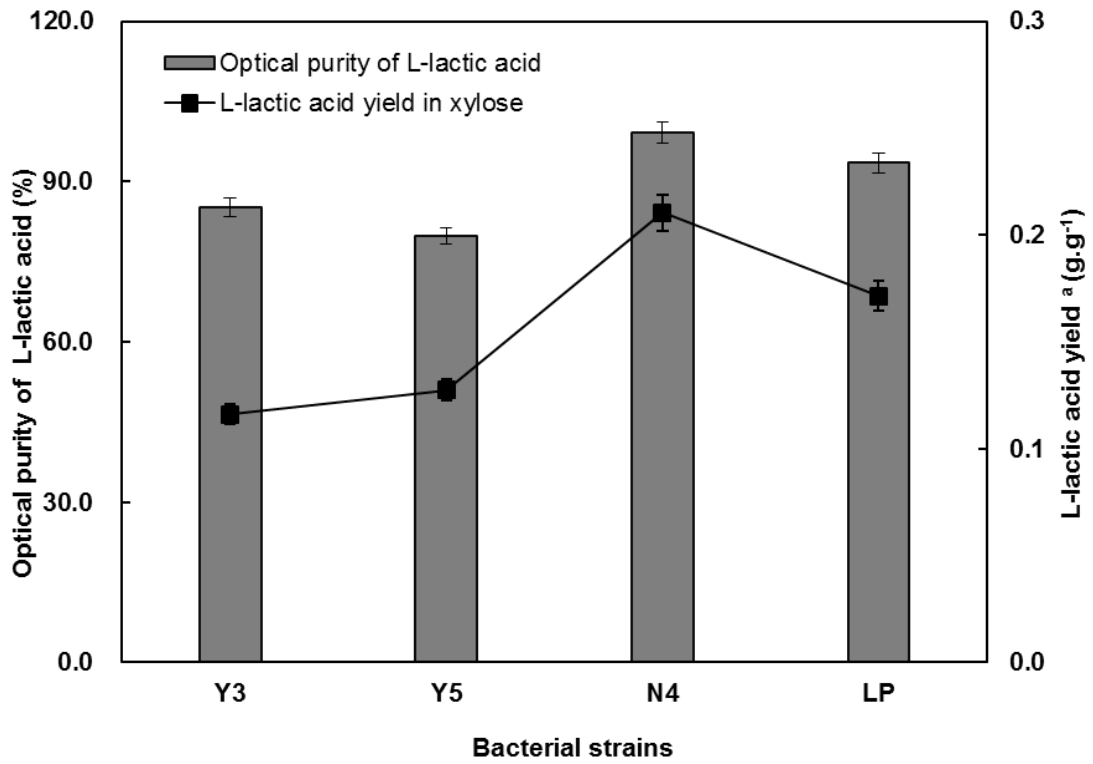

Fig. 4. L-lactic acid yield and optical purity of L-lactic acid from xylose at $37^{\circ} \mathrm{C}, 200 \mathrm{rpm}$, initial $\mathrm{pH} 7.0$ for $12 \mathrm{~h}$ fermentation (working volume $100 \mathrm{~mL}$; sugar content, $2 \%$ ); ${ }^{a}$ : Produced L-lactic acid $(\mathrm{g} / \mathrm{L})$ per glucose $(\mathrm{g} / \mathrm{L})$

\section{Analysis of L-lactic Acid Production with Xylose as the Carbon Source}

Based on the results shown in Fig. 3, the next experiments were conducted with Y3, Y5, N4, and Lactobacillus pentosus to study the lactic acid production capacity of xylose. The L-lactic acid yield and optical purity of lactic acid from xylose are shown in Fig. 4. The L-lactic acid production of the four strains is generally low because of the minimal 
lactic acid fermentation from xylose by LAB (Patel et al. 2006). Only several reported species of LAB, such as Lc. lactis IO-1, Streptococcus sp., and Lb. thermophilus T1, can metabolize xylose as a substrate to lactic acid (Oshiro et al. 2009). Figure 4 shows that the strain N4 produced more L-lactic acid than Lactobacillus pentosus, and the optical purity of lactic acid exceeded $90 \%$. Thus, it has the potential to demonstrate high productivity through genetic engineering.

\section{Analysis of L-lactic Acid Productivity}

The L-lactic acid production of the four strains from different carbon sources is shown in Figs. 5 and 6.

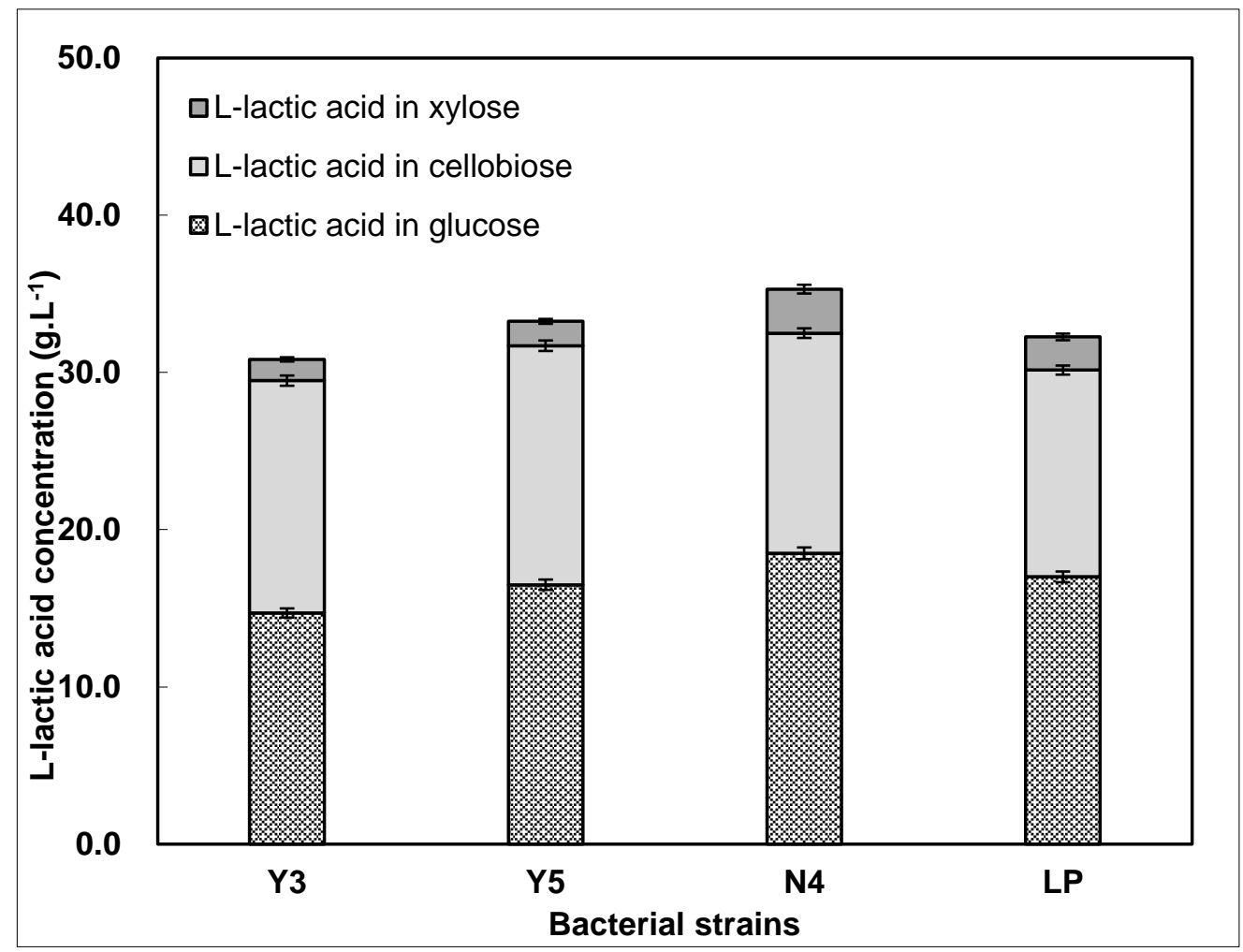

Fig. 5. Comparison of L-lactic acid production from different carbon sources at $37^{\circ} \mathrm{C}, 200 \mathrm{rpm}$, initial $\mathrm{pH} 7.0$ for $12 \mathrm{~h}$ fermentation (working volume $100 \mathrm{~mL}$; sugar content, $2 \%$ )

Strain N4 metabolized cellobiose, glucose, and xylose to produce lactic acid and obtained an L-lactic acid production of $15.1 \mathrm{~g} / \mathrm{L}, 18.5 \mathrm{~g} / \mathrm{L}$, and $2.8 \mathrm{~g} / \mathrm{L}$ carbohydrates and a productivity of $1.01 \mathrm{~g} \cdot \mathrm{L}^{-1} \cdot \mathrm{h}^{-1}, 3.68 \mathrm{~g} \cdot \mathrm{L}^{-1} \cdot \mathrm{h}^{-1}$, and $0.47 \mathrm{~g} \cdot \mathrm{L}^{-1} \cdot \mathrm{h}^{-1}$, respectively, which were higher than the values for the three other strains. The lactic acid and L-lactic acid production of strain N4 was 1.64 and 1.59 times that of Lactobacillus pentosus when cellobiose was metabolized, 1.95 and 1.40 times when glucose was metabolized, and 2.33 and 1.56 times with xylose as the substrate. This results indicated that strain N4 has great potential to produce high-purity L-lactic acid from lignocellulose-derived sugars. 


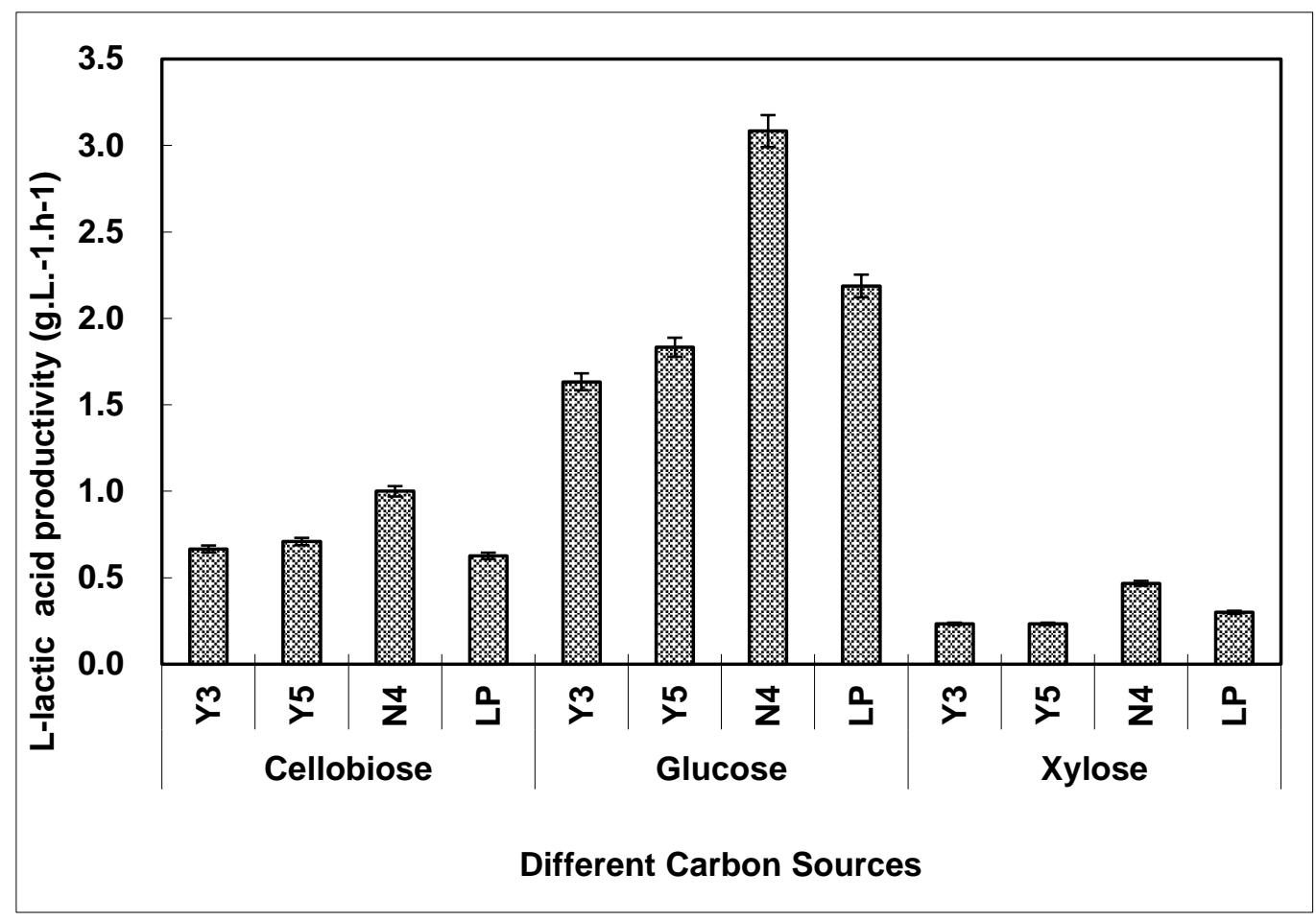

Fig. 6. L-lactic acid productivity from different carbon sources at $37^{\circ} \mathrm{C}, 200 \mathrm{rpm}$, initial $\mathrm{pH} 7.0$ for $12 \mathrm{~h}$ fermentation (working volume $100 \mathrm{~mL}$; sugar content, $2 \%$ )

According to previous studies, hemicellulose forms a substantial fraction of the lignocellulosic biomass as well as cellulose that yields pentose sugars, such as xylose, by saccharification. The majority of LAB strains can convert cellulose-derived glucose to lactic acid, but not hemicellulose-derived sugars. Among the LAB strains reported so far, only the wild-type E. mundtii QU 25 (Abdel-Rahman et al. 2010) and the genetically modified Lb. plantarum $\Delta$ ldhL1 (Okano et al. 2009) can perform homo-lactate fermentation of pentose sugars (Table 1). The strain Lc. lactis IO-1 (Tanaka et al. 2002) has been used to convert xylose to lactic acid and obtained an L-lactic acid yield of 0.62 $\mathrm{g} / \mathrm{g}$ xylose. The strain Lb. delbrueckii mutant Uc-3 (Adsul et al. 2007) and Lb. lactis mutant RM2-24 (Singhvi et al. 2010) metabolize cellobiose to lactic acid and obtained an L-lactic acid productivity of $2.05 \mathrm{~g} \cdot \mathrm{L}^{-1} \cdot \mathrm{h}^{-1}$ and $\mathrm{g} \cdot \mathrm{L}^{-1} \cdot \mathrm{h}^{-1}$, respectively.

In this study, the strain N4 converted cellobiose to lactic acid and obtained an Llactic acid yield of $0.78 \mathrm{~g} / \mathrm{g}$ and a productivity of $1.05 \mathrm{~g} \cdot \mathrm{L}^{-1} \cdot \mathrm{h}^{-1}$. When glucose was metabolized to lactic acid, it obtained an L-lactic acid yield of $0.93 \mathrm{~g} / \mathrm{g}$ and a productivity of $3.68 \mathrm{~g} \cdot \mathrm{L}^{-1} \cdot \mathrm{h}^{-1}$. When xylose was metabolized to lactic acid, it showed an L-lactic acid yield of $0.21 \mathrm{~g} / \mathrm{g}$ and a productivity of $0.47 \mathrm{~g} \cdot \mathrm{L}^{-1} \cdot \mathrm{h}^{-1}$. The lactic acid concentration by mixture of glucose, xylose and cellobiose with $\mathrm{N} 4$ is $92.7 \mathrm{~g} / \mathrm{L}$, obtained the L-lactic acid yield of $0.68 \mathrm{~g} / \mathrm{g}$ and L-lactic acid productivity of $2.03 \mathrm{~g} \cdot \mathrm{L}^{-1} \cdot \mathrm{h}^{-1}$ in batch fermentation. Thus, the isolation of strain N4 is expected to generate substantial levels of lactic acid production from lignocellulosic biomass. Lactic acid fermentation from lignocellulosederived sugars by LAB strains was achieved with different fermentation modes, as summarized in Table 1. 
Table 1. L-lactic Acid Production from Lignocellulose-derived Sugars by Lactic Acid Bacteria

\begin{tabular}{|c|c|c|c|c|}
\hline Microorganism & Substrate & $\begin{array}{c}\text { Fermentation } \\
\text { Process }\end{array}$ & $\mathrm{YL}_{\mathrm{L}-\mathrm{LA}^{\mathrm{a}}(\mathrm{g} / \mathrm{g})}$ & $\begin{array}{c}P_{L-L A}{ }^{b} \\
\left(g \cdot L^{-1} \cdot h^{-1}\right)\end{array}$ \\
\hline \multirow{5}{*}{ E. mundtii QU 25} & Cellobiose & Batch & 0.75 & 1.01 \\
\hline & Xylose & Batch & 0.76 & 0.81 \\
\hline & Glucose/cellobiose & Batch & 0.81 & 1.65 \\
\hline & Glucose/xylose & Batch & 0.78 & 1.25 \\
\hline & $\begin{array}{l}\text { Glucose/xylose/ } \\
\text { cellobiose }\end{array}$ & Batch & 0.73 & 2.01 \\
\hline $\begin{array}{l}\text { E. casseliflavus } \\
\text { and Lb. casei }\end{array}$ & Glucose/xylose & Batch & 0.68 & 1.13 \\
\hline $\begin{array}{l}\text { Lb. plantarum } \\
\Delta \text { ldhL1 }\end{array}$ & Xylose & Batch & 0.76 & 1.44 \\
\hline $\begin{array}{l}\text { Lb. delbrueckii } \\
\text { mutant Uc-3 }\end{array}$ & Cellobiose & Batch & 0.81 & 2.05 \\
\hline \multirow{2}{*}{$\begin{array}{c}\text { Lb. lactis RM 2- } \\
24\end{array}$} & Cellobiose & Batch & 0.72 & 1.51 \\
\hline & $\alpha$-Cellulose & SSF & 0.67 & 1.43 \\
\hline Lc. lactis IO-1 & Xylose & Batch & 0.62 & -- \\
\hline Lb. delbreuckii & Alfalfa fibers & SSF & 0.35 & 0.75 \\
\hline $\begin{array}{l}\text { Lb. rhamnosus } \\
\text { and Lb. brevis }\end{array}$ & Corn stover & SSF & 0.70 & 0.58 \\
\hline $\begin{array}{l}\text { Lb. bifermentans } \\
\text { DSM } 20003\end{array}$ & $\begin{array}{l}\text { Wheat bran } \\
\text { hydrolysate }\end{array}$ & $\begin{array}{l}\text { Batch with cell } \\
\text { immobilization }\end{array}$ & 0.83 & 1.17 \\
\hline $\begin{array}{l}\text { Lb. coryniformis } \\
\text { ATCC } 25600\end{array}$ & Cellulose & SSF & 0.89 & 0.50 \\
\hline \multirow{4}{*}{ Strain N4 } & Cellobiose & Batch & 0.78 & 1.05 \\
\hline & Xylose & Batch & 0.21 & 0.47 \\
\hline & Glucose & Batch & 0.93 & 3.68 \\
\hline & $\begin{array}{l}\text { Glucose/xylose/ } \\
\text { cellobiose }\end{array}$ & Batch & 0.68 & 2.03 \\
\hline
\end{tabular}

The neighbor-joining method was used to construct the phylogenetic tree of N4, and the bootstrap was 1000 . As shown in Fig. 7, Strain N4 was most closely related to Enterococcus faecium, with $98 \%$ similarity in their 16SrDNA gene sequences.

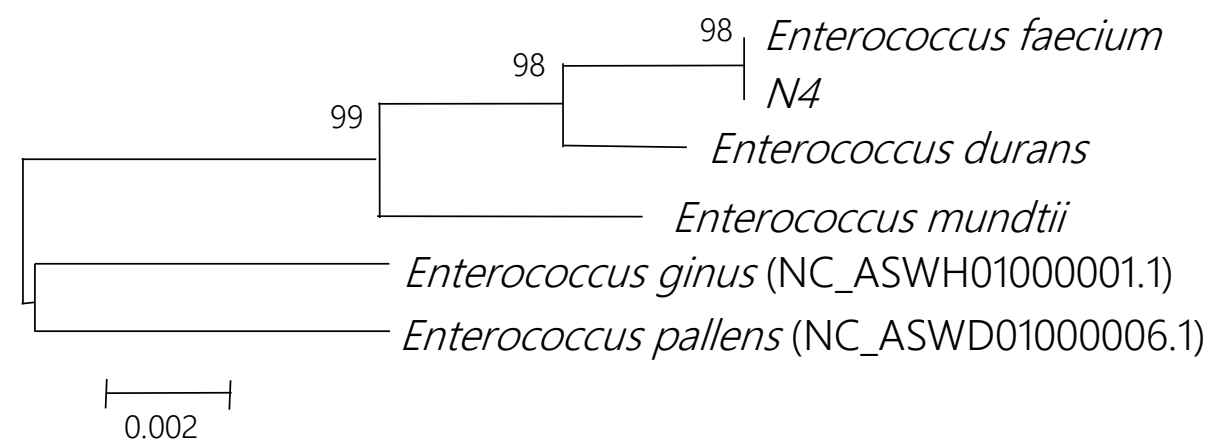

Fig. 7. Phylogenetic tree of partial $16 \mathrm{~S}$ rDNA sequences of the $\mathrm{N} 4$ strain and sequences of identified bacteria in the nucleotide database of GenBank 
Based on the above results, the authors designated strain N4 as Enterococcus faecium N4. The strain metabolized cellobiose, glucose, and xylose into high-purity Llactic acid well, and has potential for metabolizing a glucose/xylose/cellobiose mixture to L-lactic acid.

\section{CONCLUSIONS}

1. Fifteen lactic acid bacteria strains were isolated from cow dung, haystack, and sheep manure. Four strains were evaluated through Gram stain, colony morphology, and catalase activity tests.

2. Strain N4 converted cellobiose, glucose, and xylose to lactic acid and obtained a high L-lactic acid yield and the optical purity exceeded $95 \%$.

3. Through a phylogenetic tree analysis, strain N4 was most closely related to Enterococcus faecium, and the authors designated it as Enterococcus faecium N4.

\section{ACKNOWLEDGMENTS}

This research was supported by the National Natural Science Foundation (No. 21666028), the Inner Mongolia Autonomous Region Natural Science Foundation (2015BS0509); the Inner Mongolia Autonomous Region science and technology major projects.

\section{REFERENCES CITED}

Abdel-Rahman, M. A., Tashiro, Y., Zendo, T., and Sonomoto, K. (2010). "Effective 1(+)-lactic acid production by co-fermentation of mixed sugars," Journal of Biotechnology 150(3), 347-348. DOI: 10.1016/j.jbiotec.2010.09.384

Abdel-Rahman, M. A., Tashiro, Y., and Sonomoto, K. (2011). "Lactic acid production from lignocellulose-derived sugars using lactic acid bacteria: Overview and limits," Journal of Biotechnology 156(4), 286-301. DOI: 10.1016/j.jbiotec.2011.06.017

Abdel-Rahman, M. A., Tashiro, Y., Zendo, T., Shibata, K., and Sonomoto, K. (2011). "Isolation and characterisation of lactic acid bacterium for effective fermentation of cellobiose into optically pure homo 1-(+)-lactic acid," Applied Microbiology and Biotechnology 89(4), 1039-1049. DOI: 10.1007/s00253-010-2986-4

Adsul, M. G., Khire, J. M., Bastawade, K. B., and Gokhale, D. V. (2007). "Lactic acid production from cellobiose and cellotriose by Lactobacillus delbrueckii mutant Uc-3," Applied and Environmental Microbiology 73(15), 5055-5057. DOI: 10.1128/AEM.00774-07

Åkerberg, C., and Zacchi, G. (2000). "An economic evaluation of the fermentative production of lactic acid from wheat," Bioresource Technology 75(2), 119-126. DOI: 10.1016/S0960-8524(00)00057-2 
Arriola, K. G., Kim, S. C., and Adesogan, A. T. (2011). "Effect of applying inoculants with heterolactic or homolactic and heterolactic bacteria on the fermentation and quality of corn silage," Journal of Dairy Science 94(3), 1511-1516. DOI: 10.3168/jds.2010-3807

Balat, M. (2011). "Production of bioethanol from lignocellulosic materials via the biochemical pathway: A review," Energy Conversion and Management 52(2), 858875. DOI: 10.1016/j.enconman.2010.08.013

Chen, R., and Lee, Y.Y. (1997). "Membrane-mediated extractive fermentation for lactic acid production from cellulosic biomass," Appl. Biochem. Biotechnol 63,435-448. DOI: 10.1016/j.ymben.1997.05.005

Cai, Y., Benno, Y., Ogawa, M., and Kumai, S. (1999). "Effect of applying lactic acid bacteria isolated from forage crops on fermentation characteristics and aerobic deterioration of silage," Journal of Dairy Science 82(3), 520-526. DOI: 10.3168/jds.S0022-0302(99)75263-X

Chandel, A. K., Chan, E. S., Rudravaram, R., Narasu, M. L., Rao, L.V., and Ravindra, P. (2007). "Economics and environmental impact of bioethanol production technologies: An appraisal," Biotechnol. Mol. Biol. Rev 2, 14-32. DOI: 10.1016/j.apenergy.2007.02.004

Drumright, R. E., Gruber, P. R., and Henton, D. E. (2000). "Polylactic acid technology," Advanced Materials 12(23), 1841-1846. DOI: 10.1002/1521-4095(200012)12

Gao, C., Ma, C., and Xu, P. (2011). "Biotechnological routes based on lactic acid production from biomass," Biotechnology Advances 29(6), 930-939. DOI: 10.1016/j.biotechadv.2011.07.022

Hofvendahl, K., and Hahn-Hägerdal, B. (2000). "Factors affecting the fermentative lactic acid production from renewable resources," Enzyme and Microbial Technology 26(24), 87-107. DOI: 10.1016/S0141-0229(99)00155-6

John, R. P., Nampoothiri, K. M., and Pandey, A. (2007). "Fermentative production of lactic acid from biomass: An overview on process developments and future perspectives," Applied Microbiology and Biotechnology 74(3), 524-534. DOI: 10.1007/s00253-006-0779-6.

John, R. P., Nampoothiri, K. M., and Pandey, A. (2006). "Simultaneous saccharification and 1-(+)-lactic acid fermentation of protease treated wheat bran using mixed culture of lactobacilli," Biotechnol. Lett 28, 1823-1826.DOI: 10.1007/s10529-006-9159-7

Kimura, M., and Ohta, T. (1972). "On the stochastic model for estimation of mutational distance between homologous proteins," Journal of Molecular Evolution 2(1), 87-90. DOI: 10.1007/BF01653945

Levine, S. E., Fox, J. M., Blanch, H. W., and Clark, D. S. (2010). "A mechanistic model of the enzymatic hydrolysis of cellulose," Biotechnology and Bioengineering 107(1), 37-51. DOI: 10.1002/bit.22789

Lin, Y., and Tanaka, S. (2006). "Ethanol fermentation from biomass resources: Current state and prospects," Applied Microbiology and Biotechnology 69(6), 627-642. DOI: 10.1007/s00253-005-0229-X

Linko, P., Stenroos, S. L., Linko, Y., Koistinen, T., Harju, M., and Heikonen, M. (1984). "Applications of immobilized lactic acid bacteria," Ann. N. Y. Acad. Sci. 434, 406417. DOI: $10.1002 /$ bit.260260209 
Martinez, F. A. C., Balciunas, E. M., Salgado, J. M., González, J. M. D., Converti, A., and Oliveira, R. P. de S. (2013). "Lactic acid properties, applications and production: A review," Trends in Food Science \& Technology 30(1), 70-83. DOI: 10.1016/j.tifs.2012.11.007

Molina-Sabio, M., and Rodríguez-Reinoso, F. (2004). "Role of chemical activation in the development of carbon porosity," Colloids and Surfaces A: Physicochemical and Engineering Aspects 241(1-3), 15-25. DOI: 10.1016/j.colsurfa.2004.04.007

Melzoch, K., Votruba, J., Habova, V., and Rychtera, M. (1997). "Lactic acid production in a cell retention continuous culture using lignocellulosic hydrolysate as a substrate," J. Biotechnol. 56, 25-31.DOI: 10.1016/j.jbiosc.1997.07.009

Mohamed, A. A., Yukihiro, T., and Kenji, S. (2011). "Lactic acid production from lignocellulose-derived sugars using lactic acid bacteria: Overview and limits," Journal of Biotechnology 156(4), 286-301. DOI: 10.1016/j.jbiotec.2011.06.017

Neu, A. K., Pleissner, D., Mehlmann, K., Schneider, R., Puerta-Quintero, G. I., and Venus, J. (2016). "Fermentative utilization of coffee mucilage using Bacillus coagulans and investigation of down-stream processing of fermentation broth for optically pure L(+)-lactic acid production," Bioresour. Technol 211, 398-405. DOI: 10.1016/j.biortech.2016.03.122

Okano, K., Tanaka, T., Ogino, C., Fukuda, H., and Kondo, A. (2010). "Biotechnological production of enantiomeric pure lactic acid from renewable resources: Recent achievements, perspectives, and limits," Applied Microbiology and Biotechnology 85(3), 413-423. DOI: 10.1007/s00253-009-2280-5

Okano, K., Yoshida, S., Yamda, R., Tanaka, T., Ogino, C., Fukuda, H., and Kondo, A. (2009). "Improved production of homo-d-lactic acid via xylose fermentation by introduction of xylose assimilation genes and redirection of the phosphoketolase pathway to the pentose phosphate pathway in 1-lactate dehydrogenase gene-deficient Lactobacillus plantarum," Applied and Environmental Microbiology 75(24), 78587861. DOI: 10.1128/AEM.00573-09

Oshiro, M., Shinto, H., Tashiro, Y., Miwa, N., Sekiguchi, T., Okamoto, M., Ishizaki, A., and Sonomoto, K. (2009). "Kinetic modeling and sensitivity analysis of xylosemetabolism in Lactococcus lactis IO-1," Journal of Bioscience Bioengineering 108(5), 376-384. DOI: 10.1016/j.jbiosc.2009.05.003

Patel, M. A., Ou, M. S., Harbrucker, R., Aldrich, H. C., Buszko, M. L., Ingram, L. O., and Shanmugam, K. T. (2006). "Isolation and characterization of acid-tolerant, thermophilic bacteria for effective fermentation of biomass-derived sugars to lactic acid," Applied and Environmental Microbiology 72(5), 3228-3235. DOI: 10.1128/AEM.72.5.3228-3235.2006

Pessione, A., Zapponi, M., Mandili, G., Fattori, P., Mangiapane, E., Mazzoli, R., and Pessione, E. (2014). "Enantioselective lactic acid production by an Enterococcus faecium strain showing potential in agro-industrial waste bioconversion: Physiological and proteomic studies," Journal of Biotechnology 173(1), 31-40. DOI: 10.1016/j.jbiotec.2014.01.014

Sambrook, J., and Russell, D. W. (2008). Molecular Cloning: A Laboratory Manual (Sixth Edition), Cold Spring Harbor Laboratory Press, New York, NY.

Shibata, K., Flores, D. M., Kobayashi, G., and Sonomoto, K. (2007). "Direct 1-lactic acid fermentation with sago starch by a novel amylolytic lactic acid bacterium, Enterococcus faecium," Enzyme and Microbial Technology 41(1), 149-155. DOI: 10.1016/j.enzmictec.2006.12.020 
Singhvi, M., Joshi, D., Adsul, M., Varma, A., and Gokhale, D. (2010). "D-(-)-Lactic acid production from cellobiose and cellulose by Lactobacillus lactis mutant RM2-24," Green Chemistry 12(6), 1106-1109. DOI: 10.1039/B925975A

Sun, Y. M., Yuan, Z. H., and Sun, Z. J. (2006). "The status and future of bioenergy and biomass utilization in China," Renewable Energy 2, 15-21. DOI:10.3969/j.issn.16715292.2006.02.026

Sun, R., Lawther, J. M., and Banks, W. B. (1995). "Influence of alkaline pretreatments on the cell wall components of wheat straw," Ind. Crops Prod. 4, 127-145. DOI: 10.1016/j.renene.1995.01.083

Sun, Y., and Cheng, J. (2002). "Hydrolysis of lignocellulosic materials for ethanol production: A review," Bioresour. Technol. 83, 1-11. DOI: 10.1016/j.biortech.2002.03.190

Tanaka, K., Komiyama, A., Sonomoto, K., Ishizaki, A., Hall, S. J., and Stanbury, P. F. (2002). "Two different pathways for d-xylose metabolism and the effect of xylose concentration on the yield coefficient of 1-lactate in mixed-acid fermentation by the lactic acid bacterium Lactococcus lactis io-1," Applied Microbiology and Biotechnology 60(1-2), 160-167. DOI: 10.1007/s00253-002-1078-5

Temer, B., Santos, L. V., Calderón, L. A., and Pereira, G. A. G. (2014). "Expression of a bacterial xylose isomerase in an industrial strain of Saccharomyces cerevisiae," BMC Proceedings 8(4), 222. DOI: 10.1186/1753-6561-8-S4-P222

Tokuhiro, K., Ishida, N., Kondo, A., and Takahashi, H. (2008). "Lactic fermentation of cellobiose by a yeast strain displaying $\beta$-glucosidase on the cell surface," Applied Microbiology and Biotechnology 79(3), 481-488. DOI: 10.1007/s00253-008-1454-x

Tomme, P., Warren, R. A. J., and Gilkes, N. R. (1995). "Cellulose hydrolysis by bacteria and fungi," Advances in Microbial Physiology 37, 1-81. DOI: 10.1016/S00652911(08)60143-5

Xu, Z., Yang, P., Wang, Q. H., and Jiang, Z. H. (2004). “Advance on the production and application of L-lactic acid," Chemistry and Adhesion 25(4), 185-188. DOI: 10.3321/j.issn:1002-6630.2004.04.048

Xu, Z., Wang, Q. H., Wang, P., Cheng, G.S., Ji, Y. Z., Jiang, Z. H. (2007). "Production of lactic acid from soybean stalk hydrolysate with Lactobacillus sake and Lactobacillus casei," Process Biochemistry 41(1), 89-92.DOI: 10.1016/j.procbio.2006.06.015

Yang, S. J, Kataeva, I., Hamilton-Brehm, S. D., Engle, N. L., Tschaplinski, T. J., Doeppke, C., Davis, M., Westpheling, J., and Adams, M. W. W. (2009). "Efficient degradation of lignocellulosic plant biomass, without pretreatment, by the thermophilic anaerobe 'Anaerocellum thermophilum' DSM 6725,' Applied and Environmental Microbiology 75(14), 4762-4769. DOI: 10.1128/AEM.00236-09

Yu, Z. S., and Zhang, H. X. (2004). "Ethanol fermentation of acid-hydrolyzed cellulosic hyrolysate with Saccharomyces cerevisiae," Bioresour. Technol. 93, 199-204.DOI: 10.1016/j.biortech.2004.03.039

Zhang, L., Li, X., Yong, Q., Yang, S. T., Ouyang, J., and Yu, S. (2015). "Simultaneous saccharification and fermentation of xylo-oligosaccharides manufacturing waste residue for l-lactic acid production by Rhizopus oryzae," Biochemical Engineering Journal 94, 92-99. DOI: 10.1016/j.bej.2014.11.020 
Zheng, J., Gao, M., Wang, Q. H., Wang, J., Sun, X. H., Chang, Q., Tashiro, Y. (2017). "Enhancement of L-lactic acid production via synergism in open co-fermentation of Sophora flavescens residues and food waste," Bioresour. Technol 225, 159-164. DOI:10.1016/j.biortech.2016.11.055

Article submitted: May 15, 2017; Peer review completed: August 12, 2017; Revised version received and accepted: August 30, 2017; Published: September 8, 2017.

DOI: 10.15376/biores.12.4.7859-7872 